BMC

Pediatrics

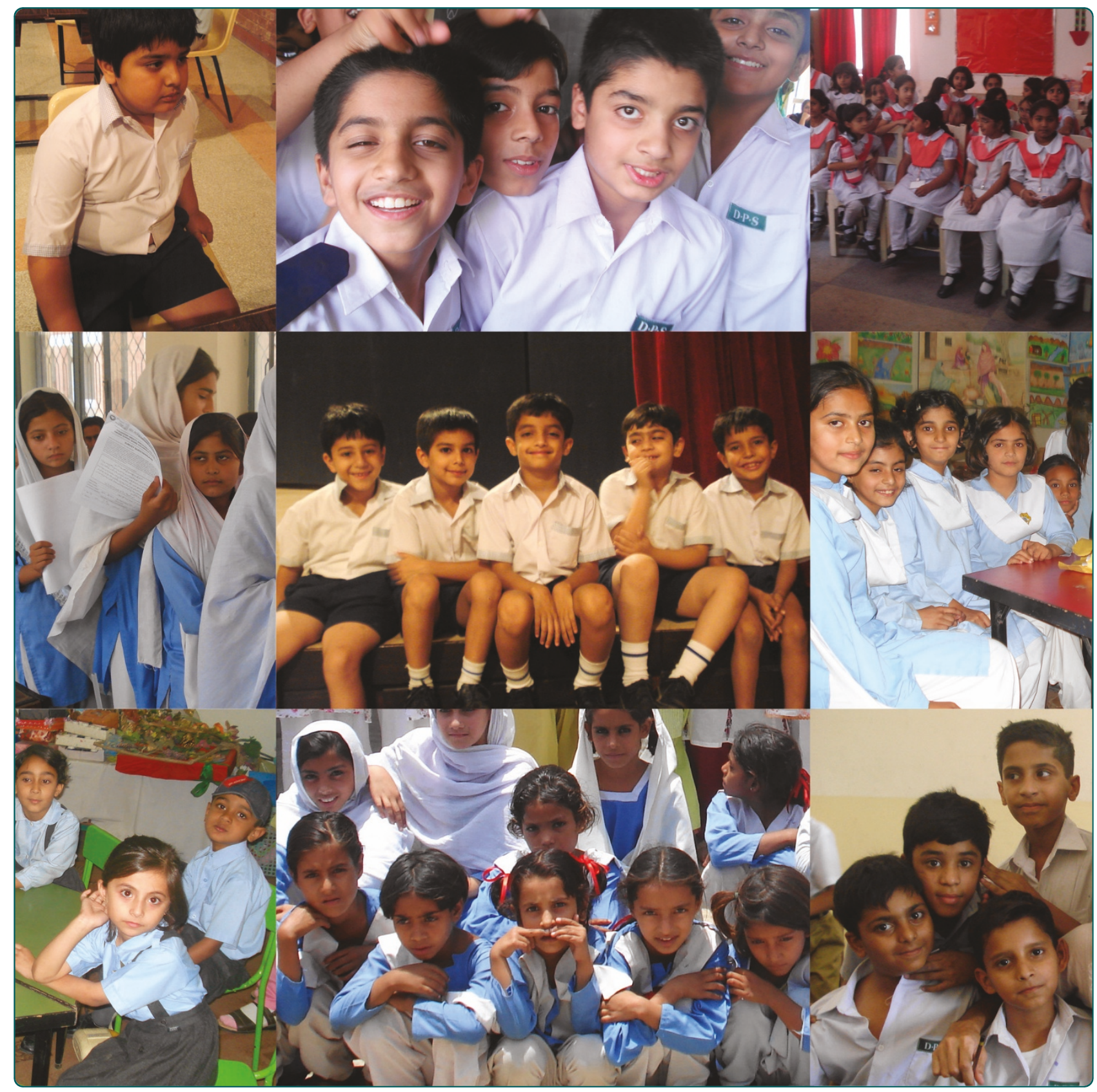

Height, weight and BMI percentiles and nutritional status relative to the international growth references among Pakistani school-aged children

Mushtaq et al. 


\title{
Height, weight and BMI percentiles and nutritional status relative to the international growth references among Pakistani school-aged children
}

Muhammad Umair Mushtaq ${ }^{1,2^{*}}$, Sibgha Gull ${ }^{1}$, Komal Mushtaq ${ }^{1}$, Hussain Muhammad Abdullah', Usman Khurshid ${ }^{1}$, Ubeera Shahid', Mushtaq Ahmad Shad ${ }^{2}$ and Javed Akram ${ }^{1}$

\begin{abstract}
Background: Child growth is internationally recognized as an important indicator of nutritional status and health in populations. This study was aimed to compare age- and gender-specific height, weight and BMI percentiles and nutritional status relative to the international growth references among Pakistani school-aged children.

Methods: A population-based study was conducted with a multistage cluster sample of 1860 children aged five to twelve years in Lahore, Pakistan. Smoothed height, weight and BMI percentile curves were obtained and comparison was made with the World Health Organization 2007 (WHO) and United States' Centers for Disease Control and Prevention 2000 (USCDC) references. Over- and under-nutrition were defined according to the WHO and USCDC references, and the International Obesity Task Force (IOTF) cut-offs. Simple descriptive statistics were used and statistical significance was considered at $\mathrm{P}<0.05$.

Results: Height, weight and BMI percentiles increased with age among both boys and girls, and both had approximately the same height and a lower weight and BMI as compared to the WHO and USCDC references. Mean differences from zero for height-, weight- and BMI-for-age $\mathrm{z}$ score values relative to the WHO and USCDC references were significant $(P<0.001)$. Means of height-for-age (present study: 0.00, WHO: -0.19 , USCDC: -0.24 ), weight-for-age (present study: 0.00, WHO: -0.22 , USCDC: -0.48 ) and BMI-for-age (present study: 0.00, WHO: -0.32, USCDC: - 0.53$)$ z score values relative to the WHO reference were closer to zero and the present study as compared to the USCDC reference. Mean differences between weight-for-age $(0.19,95 \% \mathrm{Cl} 0.10-0.30)$ and BMI-for-age $(0.21$, $95 \% \mathrm{CI} 0.11-0.30)$ z scores relative to the WHO and USCDC references were significant. Over-nutrition estimates were higher $(P<0.001)$ by the WHO reference as compared to the USCDC reference $(17 \%$ vs. $15 \%$ overweight and $7.5 \%$ vs. $4 \%$ obesity) while underweight and thinness/wasting were lower $(P<0.001)$ by the WHO reference as compared to the USCDC reference ( $7 \%$ vs. $12 \%$ underweight and $10 \%$ vs. $13 \%$ thinness). Significantly lower overweight (8\%) and obesity (5\%) prevalence and higher thinness grade one prevalence (19\%) was seen with use of the IOTF cut-offs as compared to the WHO and USCDC references. Mean difference between height-for-age $z$ scores and difference in stunting prevalence relative to the WHO and USCDC references was not significant.
\end{abstract}

Conclusion: Pakistani school-aged children significantly differed from the WHO and USCDC references. However, z score means relative to the $\mathrm{WHO}$ reference were closer to zero and the present study as compared to the USCDC

\footnotetext{
* Correspondence: mushtaqmu@gmail.com

'Ubeera Memorial Research Society, Allama Iqbal Medical College, Lahore 54000, Pakistan

Full list of author information is available at the end of the article
} 
reference. Overweight and obesity were significantly higher while underweight and thinness/wasting were significantly lower relative to the WHO reference as compared to the USCDC reference and the IOTF cut-offs. New growth charts for Pakistani children based on a nationally representative sample should be developed. Nevertheless, shifting to use of the 2007 WHO child growth reference might have important implications for child health programs and primary care pediatric clinics.

\section{Background}

Child growth is internationally recognized as an important indicator of nutritional status and health in populations [1,2]. Growth monitoring is an integral component of preventive and primary care pediatrics to evaluate individual children, and is a useful public health tool to assess child health status and economic development in the society $[3,4]$. Growth reference based on a nationally representative sample has not been developed for Pakistani children and Pakistan is one of the countries still using the 1977 National Center for Health Statistics (NCHS) reference for pediatric growth monitoring [5]. The NCHS dataset as an international growth reference has been challenged on serious technical grounds and its continued use is being discouraged [6-8]. Recently updated international height, weight, and BMI references for children and adolescents by the World Health Organization 2007 (WHO) and United States' Centers for Disease Control and Prevention 2000 (USCDC) are of interest as potentially useful for Pakistani children $[9,10]$.

Interpretation of child growth in a population depends primarily on the growth reference used [11]. Literature lacks data on nutritional parameters and indices of nutritional status with reference to international growth references among Pakistani school-aged children. This study was aimed to compare age- and gender-specific height, weight and BMI percentiles and nutritional status relative to the international growth references among Pakistani school-aged children.

\section{Methods}

\section{Design, setting and sample}

A population-based cross-sectional study titled 'Nutritional Assessment among School-going Children in Lahore, Pakistan (NASCL)' was conducted among primary school children aged five to twelve years in 20092010. Lahore, a metropolis with multiethnic populations, is the capital of Pakistan's most populous province Punjab. It has a population of nine million including 2.5 million primary school children, and $81 \%$ of the population resides in the urban area [12].

A representative multistage cluster sample of 1860 children aged five to twelve years in twelve primary schools of City District Lahore was enrolled. In the first stage, stratified random sampling, based on population and educational system characteristics, was used to have proportionate representation of gender, area of residence and socioeconomic status (SES). The list of all the public and private primary schools in Lahore was provided by the Punjab Department of Education. The listed schools were stratified according to the geographic area and monthly fee structure of schools into the following four strata: a) urban with high SES (urban area and fee $>2500$ PKR), b) urban with middle SES (urban area and fee $=1000-2500$ PKR), c) urban with low SES (urban area and fee $<1000$ PKR), and d) rural with low/disadvantaged SES (rural area and fee 100 PKR or free). The former two strata included private (including public-private mix) schools and the later two strata included public schools. Three schools were selected at random from each stratum and contacted by the Departments of Education and Health to participate voluntarily in the study. If the school administration refused to participate, next school was selected randomly from the respective stratum. For each school, a list of all classes in five grades (one to five) was obtained and one class in each grade was selected at random. In this way, sixty classes, five from each school, were selected. For each of the selected classes, first thirty-one children on class attendance register, present on data collection day and aged five to twelve years, were included in the study. Children suffering with any known metabolic syndrome (e.g. Prader-Willi syndrome) and children not willing to participate in the study were excluded. Sample size was calculated using Epi Info 6.04 d (USCDC, 2004) with a confidence (1- $\alpha$ ) of $95 \%$, anticipated prevalence of $5 \%$ and margin of error of \pm 1 . The minimum sample size calculated was 1823 and a sample of 1860 was deemed sufficient.

\section{Data collection}

The sampled schools were visited on pre-arranged dates in summer 2009. Twenty trained senior medical students including 10 males and 10 females, lead by the Principal Investigator, collected the data. Data collection activity in each school was completed in two working days and it took four weeks to complete the data collection. Health education of children and teachers was also carried out after data collection in the respective school. Analogue physician health scales, standardized before the examination, were used [13]. The instruments were 
checked and calibrated on a daily basis. Height measurement was in centimeters $(\mathrm{cm})$ to the nearest $0.1 \mathrm{~cm}$ and weight was measured in kilogram $(\mathrm{kg})$ to the nearest 0.5 $\mathrm{kg}$ with a range of $0-160 \mathrm{~kg}$. The child was asked to stand relax, feet were placed together with heels, buttocks and shoulder blades against the stick and head was positioned in the Frankfurt horizontal plane. All measurements were taken in light summer school uniform without shoes during mornings or early afternoons. The measurements were tested for reliability (one-week test-retest). For each of the sampled classes, demographic information of all officially enrolled students was obtained before data collection, including gender and date of birth. Demographic information of students not found on official rosters but currently enrolled in that class was obtained from class teachers.

Quality control measures and good practices including training, pre-testing the processes and materials, field monitoring of data collection, logistics management and daily meetings of the study teams were ensured. Informed consent statement was printed on the form. Verbal informed consent for the child to participate in the study was taken from class teachers and school heads. As the study involved no invasive procedure, verbal informed consent was deemed sufficient. The study was approved by the Ethical Review Board of Allama Iqbal Medical College, Lahore. Permissions to conduct the study were granted by the Punjab Departments of Education and Health, and the sampled schools.

\section{Statistical analysis}

Data were entered and analyzed by manual and computerized checking using SPSS version 18.0 (SPSS Inc. Chicago IL, United States, 2009). Age was calculated to the precise day by subtracting the date of birth from the date of examination. Smoothed percentile curves and $\mathrm{z}$ score values for height-, weight- and BMI-for-age relative to the present sample were obtained by the LMS method $[14,15]$. The $\mathrm{z}$ score values for height-, weightand BMI-for-age relative to the WHO 2007 reference were calculated using WHO AnthroPlus [16,17]. The WHO 2007 reference does not provide weight reference values for children older than 10 years; therefore, $\mathrm{z}$ score values for weight-for-age were calculated for five to ten years. The $\mathrm{z}$ score values relative to the USCDC 2000 reference were calculated by the SPSS files provided by the USCDC [18]. Overweight ( $>+1$ SD BMIfor-age $\mathrm{z}$ score), obesity ( $>+2 \mathrm{SD}$ BMI-for-age $\mathrm{z}$ score), thinness/wasting (<-2SD of BMI-for-age $\mathrm{z}$ score), underweight ( $<-2 \mathrm{SD}$ of weight-for-age $\mathrm{z}$ score) and stunting $(<-2 \mathrm{SD}$ of height-for-age $\mathrm{z}$ score) were defined according to the WHO and USCDC references. Weightfor-age is inadequate indicator for monitoring child growth beyond pre-school years due to its inability to distinguish between relative height and body mass, therefore, BMI-for-age is recommended by the WHO and USCDC to assess thinness/wasting in school-aged children and adolescents $[9,19]$. Overweight, obesity and thinness were also defined using the International Obesity Task Force (IOTF) cut-offs [15,20]. Difference from zero for means of height-, weight- and BMI-for-age $\mathrm{z}$ scores, relative to the WHO and USCDC references and the present study, were calculated with Student's $t$-test. Differences in height-, weight- and BMI-for-age z score means between the WHO and USCDC references were compared by paired $t$-test. McNemar test was used to compare differences in prevalence of over- and undernutrition by the WHO and USCDC references. Statistical significance was considered at $\mathrm{P}<0.05$ and all tests were two-sided.

\section{Results}

The study included a sample of 1860 primary school children aged five to twelve years. The male-female ratio was 1.11 with $52.5 \%$ boys and $47.5 \%$ girls. The sample involved $20 \%$ children from each grade and $25 \%$ children from each area and SES stratum. Seventy-five percent children were urban and $25 \%$ were rural. The median age (range) was 8 (5-12) years. Mean and standard deviation (SD) for height, weight and BMI were $128.4(11.4) \mathrm{cm}$, $26.9(8.5) \mathrm{kg}$ and $16.0(3.0) \mathrm{kg} / \mathrm{m}^{2}$ respectively (Table 1 ).

\section{Table 1 Mean and standard deviation (SD) for height, weight and BMI of Pakistani primary school children aged five to twelve years $(n=1860)$}

\begin{tabular}{|c|c|c|c|c|}
\hline Characteristics & n & Height $(\mathrm{cm})$ & Weight (kg) & $\begin{array}{l}\text { BMI } \\
\left(\mathrm{kg} / \mathrm{m}^{2}\right)\end{array}$ \\
\hline \multicolumn{5}{|l|}{ Boys ( $n=977$ ) } \\
\hline 5 years (61-71 months) & 84 & $113.7(7.3)$ & $19.9(4.6)$ & $15.2(2.1)$ \\
\hline 6 years (72-83 months) & 161 & $118.3(5.9)$ & $21.6(5.0)$ & $15.3(2.8)$ \\
\hline 7 years (84-95 months) & 160 & $122.9(8.0)$ & $23.5(5.1)$ & $15.5(2.4)$ \\
\hline 8 years (96-107 months) & 158 & $128.7(7.6)$ & $26.9(5.9)$ & $16.1(2.5)$ \\
\hline 9 years (108-119 months) & 161 & $134.2(8.1)$ & $29.7(7.6)$ & $16.4(3.1)$ \\
\hline 10 years (120-131 months) & 147 & $138.4(8.0)$ & $33.3(9.5)$ & $17.2(3.5)$ \\
\hline 11 years (132-143 months) & 69 & $138.6(7.7)$ & $31.8(6.8)$ & $16.5(2.7)$ \\
\hline 12 years (144-155 months) & 37 & $140.0(8.3)$ & $31.8(7.3)$ & $16.1(2.3)$ \\
\hline \multicolumn{5}{|l|}{ Girls ( $n=883$ ) } \\
\hline 5 years (61-71 months) & 72 & $115.4(7.3)$ & $19.3(3.2)$ & $14.4(1.5)$ \\
\hline 6 years (72-83 months) & 143 & $119.1(7.6)$ & $21.0(4.9)$ & $14.7(2.4)$ \\
\hline 7 years (84-95 months) & 157 & $124.0(6.3)$ & $24.0(5.5)$ & $15.5(2.7)$ \\
\hline 8 years (96-107 months) & 159 & $128.1(7.1)$ & $26.4(6.8)$ & $15.9(2.9)$ \\
\hline 9 years (108-119 months) & 151 & $133.3(7.8)$ & $30.4(8.2)$ & $17.0(3.5)$ \\
\hline 10 years (120-131 months) & 120 & $138.4(9.3)$ & $33.3(10.1)$ & $17.2(3.8)$ \\
\hline 11 years (132-143 months) & 62 & $143.3(9.6)$ & $36.5(11.0)$ & $17.5(3.7)$ \\
\hline 12 years (144-155 months) & 19 & $146.0(9.4)$ & $36.4(9.9)$ & $16.9(3.3)$ \\
\hline
\end{tabular}


Age- and gender-specific height percentiles (Table 2, Figure 1), age- and gender-specific weight percentiles (Table 3, Figure 2), and age- and gender-specific BMI percentiles (Table 4, Figure 3) were developed and smoothed by the LMS method. Among both boys and girls, height, weight and BMI increased with age. Fiftieth percentile curves for height, weight and BMI of the present sample were compared with the international growth references, the WHO 2007 and USCDC 2000. In younger age groups, boys had approximately the same height while girls were taller; and after nine years of age both boys and girls fell short as compared to the WHO and USCDC references (Figure 4). Both boys and girls had lower weight (Figure 5), and lower BMI (Figure 6), as compared to the WHO and USCDC references.

Mean differences from zero for height-, weight- and BMI-for-age $\mathrm{z}$ score values relative to the WHO and USCDC references were significant $(\mathrm{P}<0.001)$. Means of height-for-age (present study: 0.00, 95\% CI -0.05 to 0.05; WHO: -0.19 , 95\% CI -0.25 to -0.13 ; USCDC: -0.24 , $95 \%$ CI -0.30 to -0.18 ), weight-for-age (present study: 0.00, 95\% CI -0.05 to 0.05 ; WHO: -0.22 , 95\% CI -0.29 to -0.18 ; USCDC: $-0.48,95 \%$ CI -0.54 to -0.41 ) and BMI-for-age (present study: $0.00,95 \%$ CI -0.04 to 0.04 ; WHO: -0.32 , 95\% CI -0.59 to -0.46 ; USCDC: $-0.53,95 \% \mathrm{CI}:-0.59$ to -0.46) z score values relative to the WHO reference were closer to zero and the present study as compared to the USCDC reference (Table 5, Table 6, Table 7).
Differences in means of $\mathrm{z}$ score values for weightfor-age (boys: $0.23,95 \%$ CI $0.09-0.36, \mathrm{P}=0.001$; girls: $0.17,95 \%$ CI 0.03 to $0.31, \mathrm{P}=0.020$; total: $0.19,95 \%$ CI 0.10-0.30, P < 0.001) and BMI-for-age (boys: 0.21, 95\% CI 0.07-0.35, P = 0.003; girls: 0.20 , 95\% CI 0.07$0.34, \mathrm{P}=0.004$; total: $0.21,95 \%$ CI $0.11-0.30, \mathrm{P}<$ 0.001 ) relative to the $\mathrm{WHO}$ and USCDC references were significant. Difference in means of $\mathrm{z}$ score values for height-for-age relative to the WHO and USCDC references was not significant (boys: $0.05,95 \%$ CI -0.16 to 0.05 ; girls: $0.04,95 \% \mathrm{CI}-0.17$ to 0.08 ; total: 0.05 , 95\% CI -0.03 to 0.13$)$.

Over-nutrition estimates were significantly higher ( $\mathrm{P}$ $<0.001$ ) by the WHO reference as compared to the USCDC reference (17\% vs. $15 \%$ overweight and $7.5 \%$ vs. $4 \%$ obesity). The same trend was observed among both boys ( $17 \%$ vs. $14 \%$ overweight and $9 \%$ vs. $5 \%$ obesity) and girls (16.5\% vs. $15 \%$ overweight and $6 \%$ vs. $3 \%$ obesity) (Table 8). Estimates for underweight and thinness/wasting were significantly lower $(\mathrm{P}<0.001)$ by the WHO reference as compared to the USCDC reference ( $7 \%$ vs. $12 \%$ underweight and $10 \%$ vs. $13 \%$ thinness). The same trend was observed among both among boys ( $7 \%$ vs. $13 \%$ underweight and $10 \%$ vs. $13 \%$ thinness) and girls (6\% vs. $12 \%$ underweight and $10 \%$ vs. $13.5 \%$ thinness) (Table 9 ). Difference in stunting prevalence was not significant between the WHO and USCDC references among boys and girls. When the

Table 2 Age- and gender-specific smoothed height percentiles for Pakistani primary school children aged five to twelve years $(n=1860)$

\begin{tabular}{|c|c|c|c|c|c|c|c|c|c|}
\hline \multirow[t]{2}{*}{ Characteristics } & \multicolumn{9}{|c|}{ Percentiles } \\
\hline & $3^{\text {rd }}$ & $5^{\text {th }}$ & $10^{\text {th }}$ & $25^{\text {th }}$ & $50^{\text {th }}$ & $75^{\text {th }}$ & $90^{\text {th }}$ & $95^{\text {th }}$ & $97^{\text {th }}$ \\
\hline \multicolumn{10}{|l|}{ Boys $(n=977)$} \\
\hline 5 years (61-71 months) & 101.5 & 102.9 & 105.2 & 109.0 & 113.3 & 117.6 & 121.5 & 123.8 & 125.3 \\
\hline 6 years (72-83 months) & 105.8 & 107.4 & 109.7 & 113.7 & 118.2 & 122.7 & 126.9 & 129.3 & 131.0 \\
\hline 7 years (84-95 months) & 110.6 & 112.2 & 114.6 & 118.8 & 123.5 & 128.3 & 132.7 & 135.3 & 137.1 \\
\hline 8 years (96-107 months) & 115.1 & 116.8 & 119.3 & 123.7 & 128.6 & 133.7 & 138.3 & 141.1 & 143.0 \\
\hline 9 years (108-119 months) & 119.2 & 120.9 & 123.6 & 128.1 & 133.3 & 138.5 & 143.4 & 146.4 & 148.4 \\
\hline 10 years (120-131 months) & 122.8 & 124.5 & 127.2 & 131.9 & 137.2 & 142.7 & 147.8 & 150.9 & 153.0 \\
\hline 11 years (132-143 months) & 125.7 & 127.5 & 130.2 & 135.0 & 140.5 & 146.2 & 151.5 & 154.8 & 156.9 \\
\hline 12 years (144-155 months) & 128.2 & 130.0 & 132.8 & 137.6 & 143.2 & 149.1 & 154.6 & 158.0 & 160.3 \\
\hline \multicolumn{10}{|l|}{ Girls $(n=883)$} \\
\hline 5 years (61-71 months) & 102.9 & 104.2 & 106.3 & 109.9 & 114.1 & 118.6 & 122.9 & 125.6 & 127.4 \\
\hline 6 years (72-83 months) & 106.8 & 108.2 & 110.4 & 114.3 & 118.7 & 123.5 & 127.9 & 130.7 & 132.5 \\
\hline 7 years (84-95 months) & 110.7 & 112.2 & 114.6 & 118.7 & 123.4 & 128.3 & 133.0 & 135.8 & 137.7 \\
\hline 8 years (96-107 months) & 114.7 & 116.3 & 118.9 & 123.2 & 128.2 & 133.4 & 138.2 & 141.1 & 143.0 \\
\hline 9 years (108-119 months) & 118.8 & 120.6 & 123.3 & 128.0 & 133.3 & 138.7 & 143.6 & 146.6 & 148.6 \\
\hline 10 years (120-131 months) & 123.1 & 125.0 & 127.9 & 132.9 & 138.5 & 144.1 & 149.2 & 152.3 & 154.3 \\
\hline 11 years (132-143 months) & 127.3 & 129.3 & 132.5 & 137.8 & 143.7 & 149.6 & 154.9 & 158.0 & 160.1 \\
\hline 12 years (144-155 months) & 131.2 & 133.4 & 136.8 & 142.4 & 148.6 & 154.8 & 160.2 & 163.4 & 165.5 \\
\hline
\end{tabular}




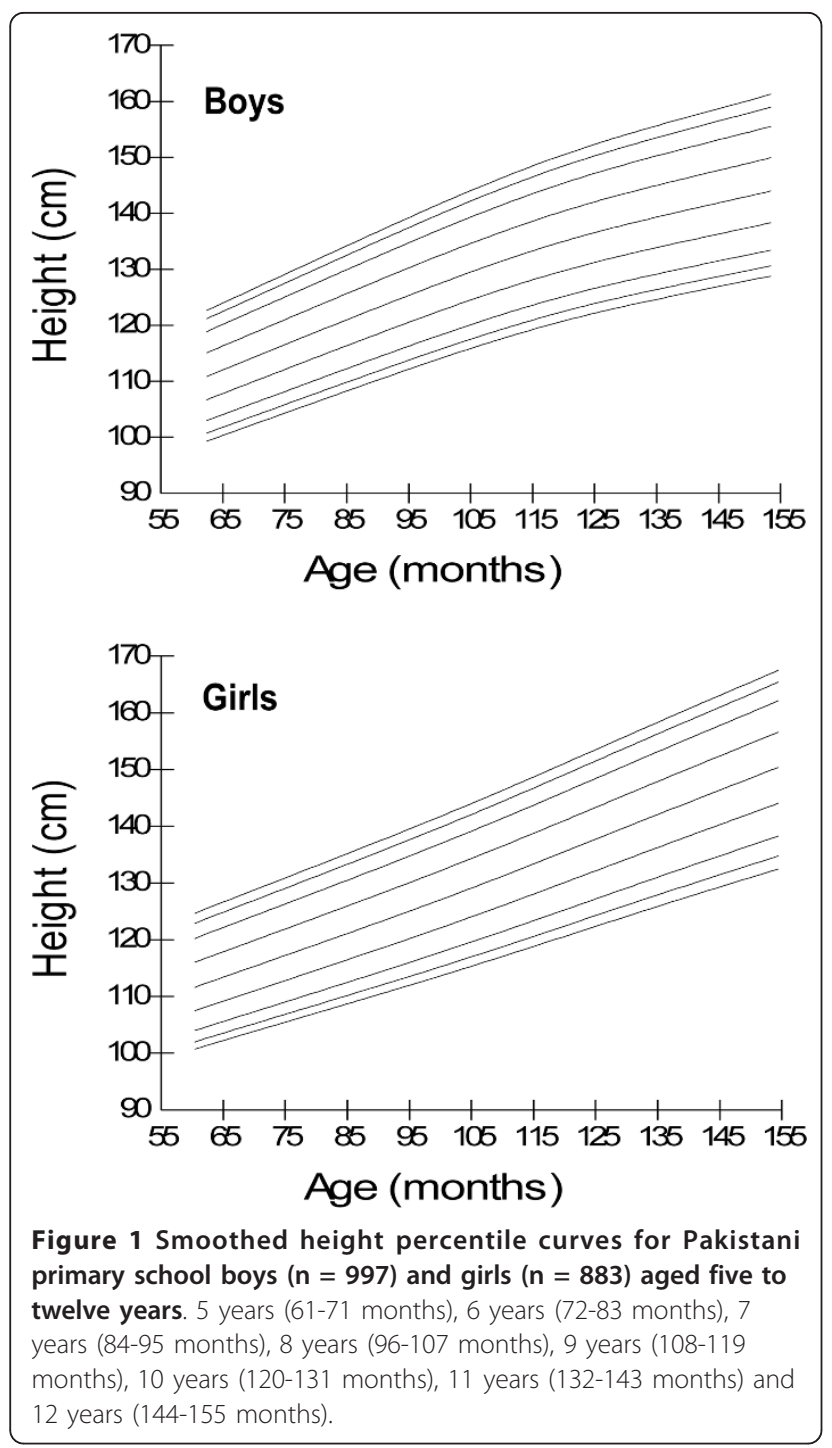

IOTF cut-offs were used, overweight and obesity prevalence was $8 \%$ and $5 \%$ respectively $(8 \%$ and $4 \%$ respectively among boys and $9 \%$ and $5 \%$ respectively among girls). Thinness prevalence was 19\% (grade one), $6 \%$ (grade two) and $4 \%$ (grade three). Thinness among boys was $18 \%$ (grade one), $5 \%$ (grade two) and $4 \%$ (grade three) while among girls it was 19\% (grade one), $8 \%$ (grade two) and 3.5\% (grade three). Overweight was significantly lower with use of the IOTF cut-offs as compared to the WHO $(\mathrm{P}<0.001)$ and USCDC $(\mathrm{P}<0.001)$ references. Obesity prevalence was also significantly lower with use of the IOTF cut-offs as compared to the WHO $(\mathrm{P}<0.001)$ and USCDC (P $=0.017)$ references. Significantly higher thinness (grade one) prevalence was seen with use of the IOTF cut-offs as compared to the WHO $(\mathrm{P}<0.001)$ and USCDC (P $<0.001)$ references.
Table 3 Age- and gender-specific smoothed weight percentiles for Pakistani primary school children aged five to twelve years $(n=1860)$

\begin{tabular}{|c|c|c|c|c|c|c|c|c|c|}
\hline \multirow[t]{2}{*}{ Characteristics } & \multicolumn{9}{|c|}{ Percentiles } \\
\hline & $3^{\text {rd }}$ & $5^{\text {th }}$ & $10^{\text {th }}$ & $25^{\text {th }}$ & $50^{\text {th }}$ & $75^{\text {th }}$ & $90^{\text {th }}$ & $95^{\text {th }}$ & $97^{\text {th }}$ \\
\hline \multicolumn{10}{|l|}{ Boys ( $n=977$ ) } \\
\hline $\begin{array}{l}5 \text { years (61-71 } \\
\text { months) }\end{array}$ & 14.0 & 14.4 & 15.1 & 16.6 & 18.6 & 21.1 & 24.2 & 26.5 & 28.3 \\
\hline $\begin{array}{l}6 \text { years }(72-83 \\
\text { months) }\end{array}$ & 15.4 & 15.9 & 16.8 & 18.4 & 20.8 & 23.8 & 27.4 & 30.1 & 32.2 \\
\hline $\begin{array}{l}7 \text { years (84-95 } \\
\text { months) }\end{array}$ & 17.0 & 17.5 & 18.5 & 20.5 & 23.2 & 26.7 & 30.9 & 34.2 & 36.7 \\
\hline $\begin{array}{l}8 \text { years (96-107 } \\
\text { months) }\end{array}$ & 18.5 & 19.2 & 20.3 & 22.5 & 25.6 & 29.7 & 34.7 & 38.5 & 41.4 \\
\hline $\begin{array}{l}9 \text { years (108-119 } \\
\text { months) }\end{array}$ & 19.9 & 20.7 & 22.0 & 24.5 & 28.0 & 32.7 & 38.3 & 42.7 & 46.2 \\
\hline $\begin{array}{l}10 \text { years (120-131 } \\
\text { months) }\end{array}$ & 21.1 & 22.0 & 23.4 & 26.2 & 30.1 & 35.3 & 41.7 & 46.7 & 50.6 \\
\hline $\begin{array}{l}11 \text { years (132-143 } \\
\text { months) }\end{array}$ & 22.1 & 23.0 & 24.6 & 27.6 & 32.0 & 37.7 & 44.8 & 50.3 & 54.6 \\
\hline $\begin{array}{l}12 \text { years (144-155 } \\
\text { months) }\end{array}$ & 22.9 & 23.9 & 25.5 & 28.8 & 33.5 & 39.8 & 47.5 & 53.5 & 58.2 \\
\hline \multicolumn{10}{|l|}{ Girls ( $n=883$ ) } \\
\hline $\begin{array}{l}5 \text { years (61-71 } \\
\text { months) }\end{array}$ & 13.8 & 14.2 & 14.9 & 16.2 & 18.0 & 20.3 & 22.9 & 24.8 & 26.2 \\
\hline $\begin{array}{l}6 \text { years }(72-83 \\
\text { months) }\end{array}$ & 15.2 & 15.7 & 16.5 & 18.1 & 20.3 & 23.1 & 26.5 & 29.0 & 31.0 \\
\hline $\begin{array}{l}7 \text { years (84-95 } \\
\text { months) }\end{array}$ & 16.6 & 17.2 & 18.2 & 20.1 & 22.8 & 26.3 & 30.6 & 33.8 & 36.4 \\
\hline $\begin{array}{l}8 \text { years (96-107 } \\
\text { months) }\end{array}$ & 18.1 & 18.7 & 19.9 & 22.2 & 25.4 & 29.8 & 35.1 & 39.3 & 42.6 \\
\hline $\begin{array}{l}9 \text { years (108-119 } \\
\text { months) }\end{array}$ & 19.6 & 20.4 & 21.7 & 24.4 & 28.3 & 33.5 & 40.1 & 45.4 & 49.5 \\
\hline $\begin{array}{l}10 \text { years (120-131 } \\
\text { months) }\end{array}$ & 21.0 & 21.9 & 23.5 & 26.7 & 31.2 & 37.5 & 45.5 & 51.9 & 57.1 \\
\hline $\begin{array}{l}11 \text { years (132-143 } \\
\text { months) }\end{array}$ & 22.3 & 23.4 & 25.2 & 28.8 & 34.2 & 41.5 & 51.0 & 58.8 & 65.1 \\
\hline $\begin{array}{l}12 \text { years (144-155 } \\
\text { months) }\end{array}$ & 23.5 & 24.7 & 26.7 & 30.8 & 36.9 & 45.4 & 56.5 & 65.7 & 73.1 \\
\hline
\end{tabular}

\section{Discussion}

Child under-nutrition is estimated to be the largest contributor to global burden of disease, killing millions of children and causing heavy health expenditures in the developing countries particularly South Asia [21-25]. Childhood obesity is a global epidemic that is now penetrating the developing countries including Pakistan, especially amongst the urban [25-29]. Interpretation of child growth in a population depends primarily on the growth reference used, and literature lacks data on indices of nutritional status with reference to the WHO and USCDC references that are potentially useful for Pakistani children [9-11]. The present study is first to report comparison of international growth references among Pakistani school-aged children. 


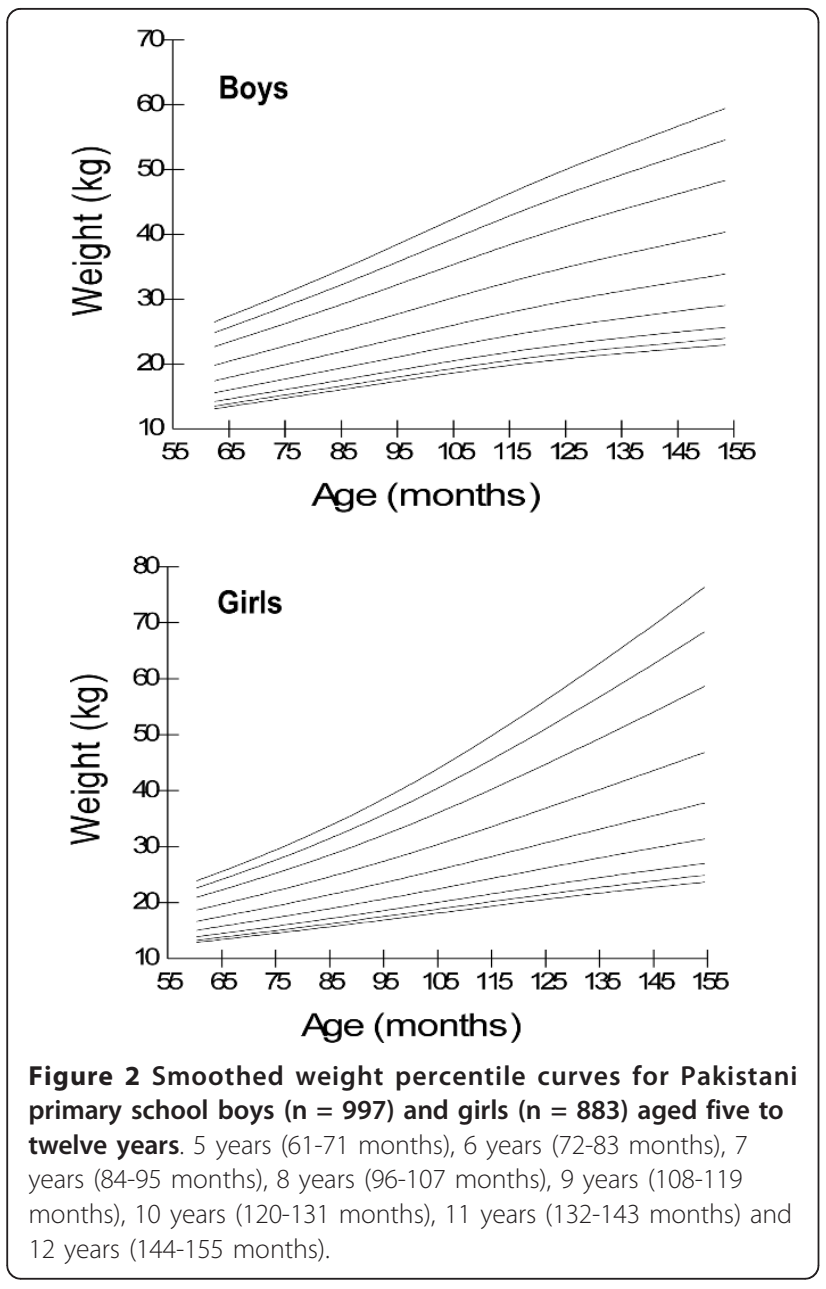

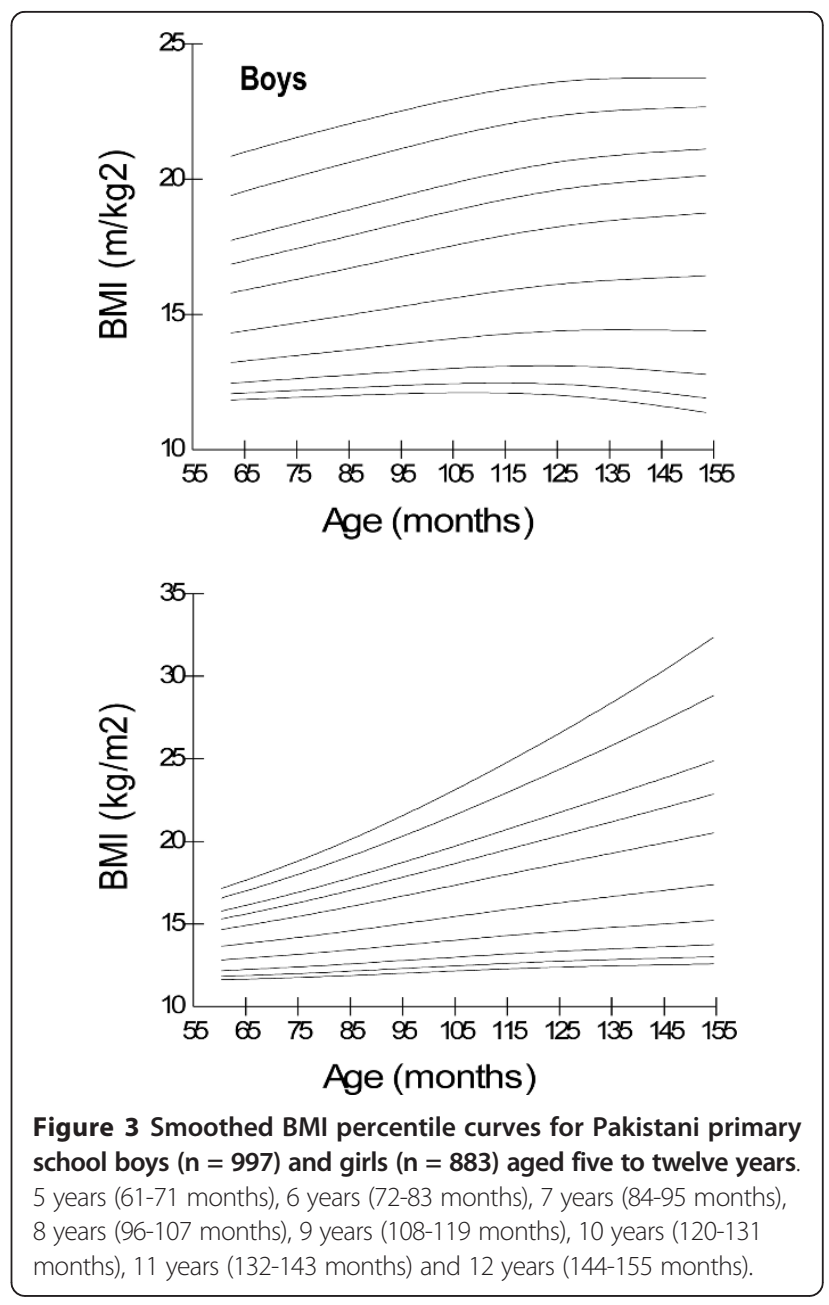

Table 4 Age- and gender-specific smoothed BMI percentiles for Pakistani primary school children aged five to twelve years $(n=1860)$

\begin{tabular}{|c|c|c|c|c|c|c|c|c|c|c|}
\hline \multirow[t]{2}{*}{ Characteristics } & \multicolumn{10}{|c|}{ Percentiles } \\
\hline & $3^{\text {rd }}$ & $5^{\text {th }}$ & $10^{\text {th }}$ & $25^{\text {th }}$ & $50^{\text {th }}$ & $75^{\text {th }}$ & $85^{\text {th }}$ & $90^{\text {th }}$ & $95^{\text {th }}$ & $97^{\text {th }}$ \\
\hline \multicolumn{11}{|l|}{ Boys $(n=977)$} \\
\hline 5 years (61-71 months) & 11.7 & 12.0 & 12.5 & 12.5 & 13.4 & 14.6 & 16.1 & 17.0 & 17.7 & 19.6 \\
\hline 6 years (72-83 months) & 11.7 & 12.0 & 12.6 & 12.6 & 13.6 & 14.9 & 16.5 & 17.5 & 18.2 & 20.2 \\
\hline 7 years (84-95 months) & 11.8 & 12.2 & 12.8 & 12.8 & 13.9 & 15.3 & 17.0 & 18.0 & 18.8 & 20.8 \\
\hline 8 years (96-107 months) & 11.8 & 12.2 & 12.9 & 12.9 & 14.1 & 15.7 & 17.5 & 18.6 & 19.3 & 21.4 \\
\hline 9 years (108-119 months) & 11.8 & 12.3 & 13.0 & 13.0 & 14.3 & 16.0 & 17.9 & 19.0 & 19.9 & 22.0 \\
\hline 10 years (120-131 months) & 11.7 & 12.2 & 13.0 & 13.0 & 14.5 & 16.3 & 18.3 & 19.5 & 20.3 & 22.5 \\
\hline 11 years (132-143 months) & 11.5 & 12.1 & 13.0 & 13.0 & 14.6 & 16.5 & 18.6 & 19.8 & 20.7 & 22.8 \\
\hline 12 years (144-155 months) & 11.1 & 11.8 & 12.8 & 12.8 & 14.6 & 16.7 & 18.9 & 20.2 & 21.0 & 23.1 \\
\hline \multicolumn{11}{|l|}{ Girls $(n=883)$} \\
\hline 5 years (61-71 months) & 11.7 & 11.9 & 12.3 & 12.9 & 13.8 & 14.8 & 15.4 & 15.9 & 16.7 & 17.3 \\
\hline 6 years (72-83 months) & 11.8 & 12.1 & 12.5 & 13.2 & 14.2 & 15.4 & 16.2 & 16.8 & 17.8 & 18.6 \\
\hline 7 years (84-95 months) & 12.0 & 12.2 & 12.7 & 13.5 & 14.7 & 16.1 & 17.1 & 17.8 & 19.1 & 20.1 \\
\hline 8 years (96-107 months) & 12.2 & 12.4 & 12.9 & 13.9 & 15.2 & 16.9 & 18.1 & 19.0 & 20.6 & 21.9 \\
\hline 9 years (108-119 months) & 12.3 & 12.6 & 13.2 & 14.2 & 15.7 & 17.7 & 19.1 & 20.2 & 22.2 & 23.8 \\
\hline 10 years (120-131 months) & 12.5 & 12.8 & 13.4 & 14.6 & 16.2 & 18.5 & 20.1 & 21.4 & 23.8 & 25.9 \\
\hline 11 years (132-143 months) & 12.6 & 12.9 & 13.6 & 14.8 & 16.7 & 19.2 & 21.1 & 22.6 & 25.5 & 28.0 \\
\hline 12 years (144-155 months) & 12.7 & 13.1 & 13.8 & 15.2 & 17.3 & 20.3 & 22.5 & 24.4 & 28.1 & 31.4 \\
\hline
\end{tabular}




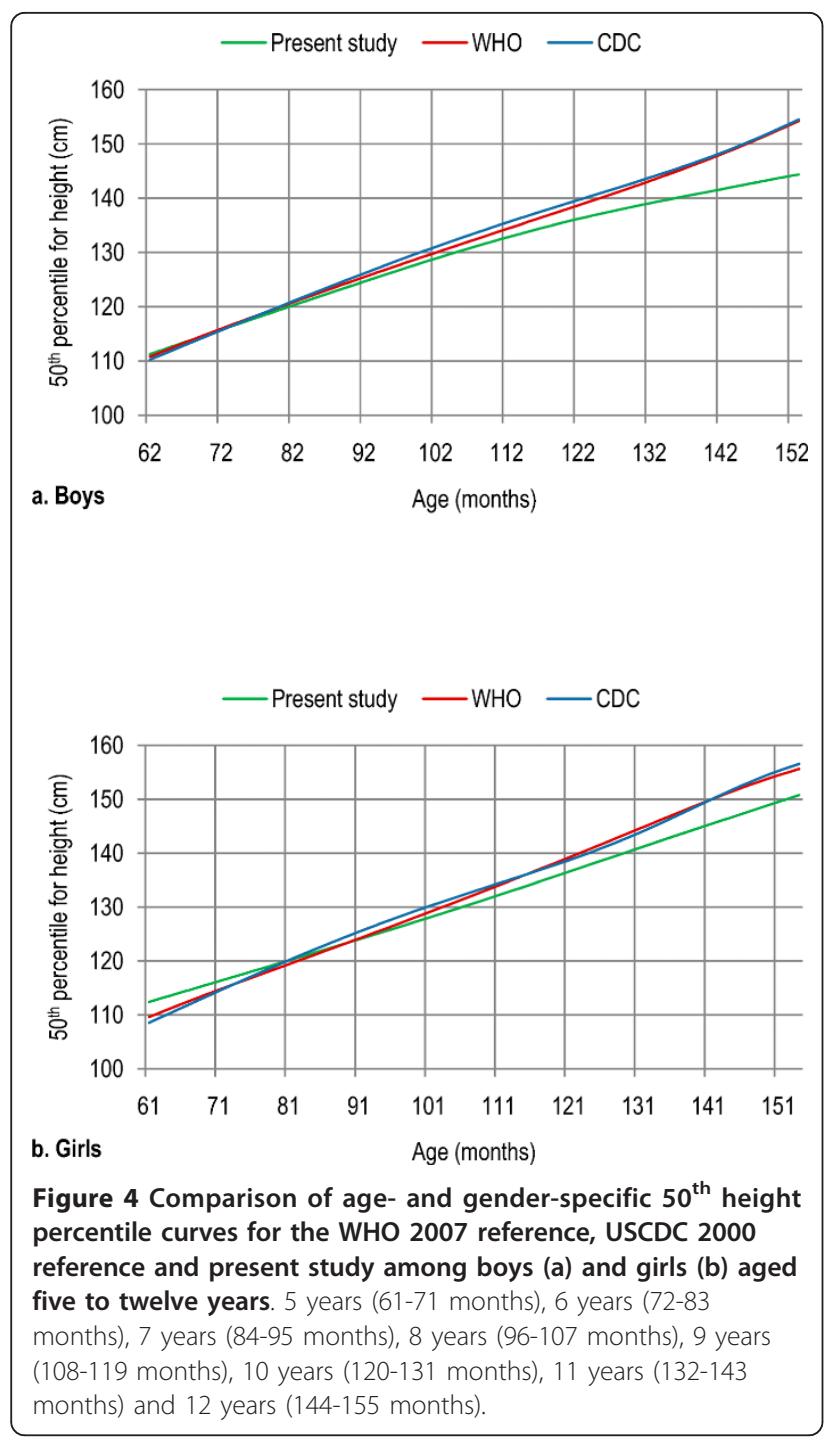

Height, weight and BMI increased with age among both boys and girls. Girls showed a sharp increase in weight and BMI after nine years of age possibly because of pubertal growth spurt that is more pronounced in girls in this age group. Both boys and girls had approximately the same height and lower weight and BMI as compared to the WHO and USCDC references. Previous studies in various countries reported a significant difference of the native children with the WHO and USCDC samples and development of a nationally representative growth reference was suggested for each country [30-33]. Lower BMI cut-off points may need to be set for Asian populations, due to their predisposition to obesity [34-38].

Mean differences from zero for height-, weight- and BMI-for-age $\mathrm{z}$ scores relative to the WHO and USCDC references were significant; however, $\mathrm{z}$ score means relative to the WHO reference were closer to zero and the

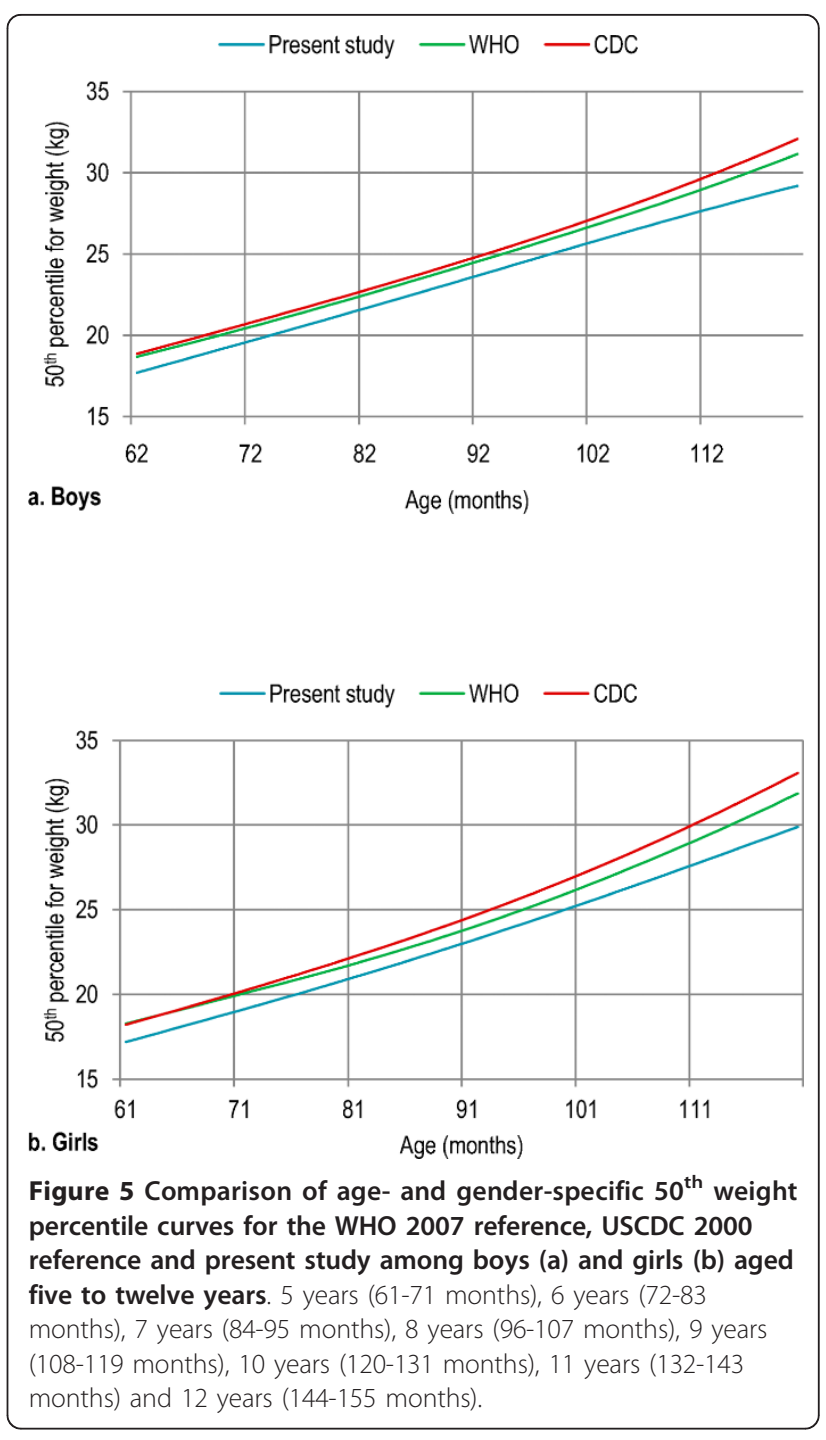

present study as compared to the USCDC reference. Mean differences between weight-and BMI-for-age $\mathrm{z}$ scores relative to the WHO and USCDC references were significant. Overweight and obesity were significantly higher by the WHO reference as compared to the USCDC reference while underweight and thinness/wasting were significantly lower by the WHO reference as compared to the USCDC reference. Difference between the WHO and USCDC height-for-age $\mathrm{z}$ score means and estimates for stunting by the WHO and USCDC references was not significant. Previous studies reported a lower prevalence of underweight and stunting while a higher prevalence of overweight and obesity using the WHO reference compared to the USCDC reference [39-42]. The USCDC growth charts over-estimate the under-nutrition and under-estimate the over-nutrition. The WHO reference has been recommended as a better choice as compared to the USCDC reference and IOTF 


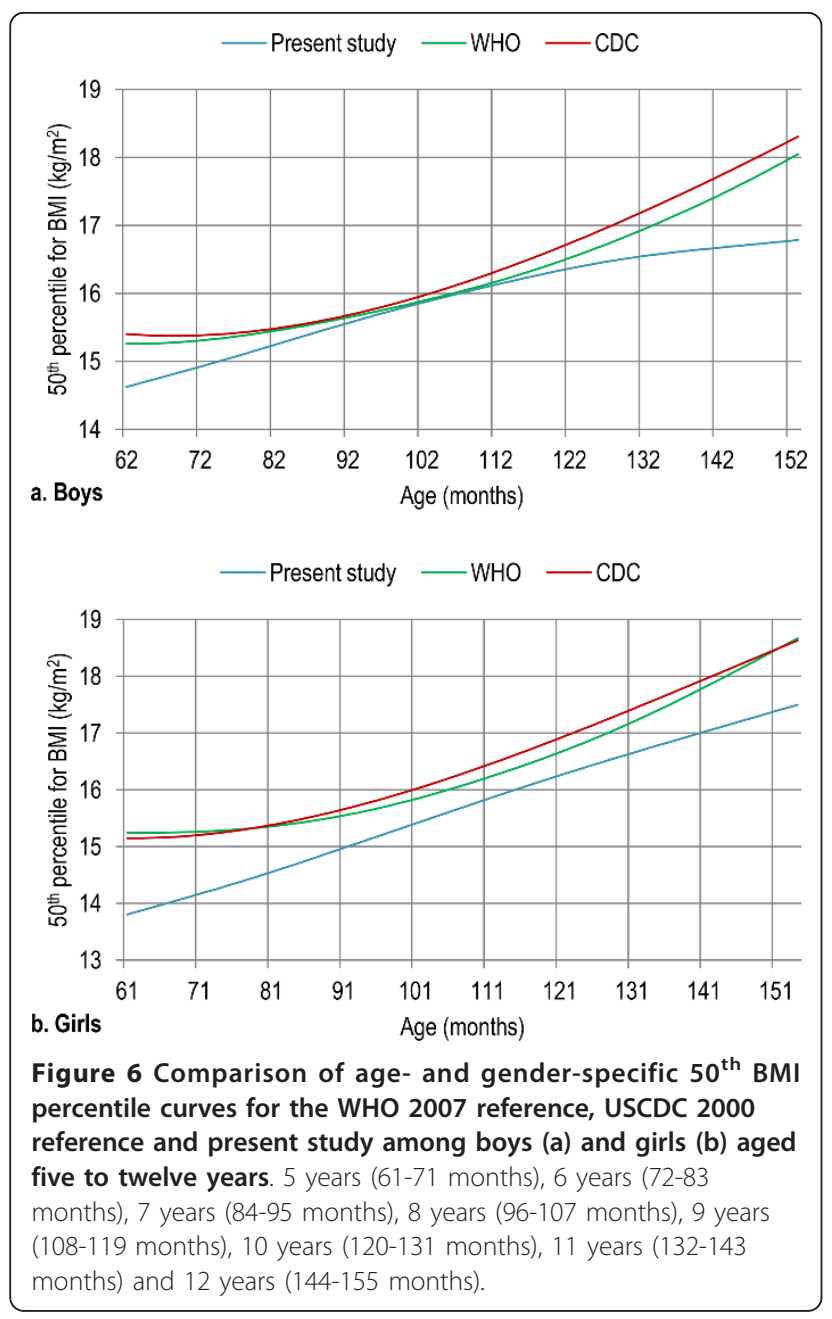

Table 5 Height-for-age $\mathbf{z}$ scores relative to the international growth references for Pakistani primary school children aged five to twelve years

\begin{tabular}{|c|c|c|c|c|}
\hline \multirow[t]{2}{*}{ Reference } & \multicolumn{4}{|c|}{ Height-for-age z scores } \\
\hline & Mean & $95 \% \mathrm{Cl}$ & SD & $P$ value ${ }^{a}$ \\
\hline \multicolumn{5}{|l|}{ Boys $(n=977)$} \\
\hline WHO 2007 & -0.25 & -0.33 to -0.17 & 1.31 & $<0.001$ \\
\hline USCDC 2000 & -0.31 & -0.90 to -0.22 & 1.29 & $<0.001$ \\
\hline Present study & 0.00 & -0.06 to 0.06 & 1.00 & 0.990 \\
\hline \multicolumn{5}{|l|}{ Girls $(n=883)$} \\
\hline WHO 2007 & -0.12 & -0.21 to -0.03 & 1.33 & $<0.001$ \\
\hline USCDC 2000 & -0.16 & -0.24 to -0.07 & 1.29 & $<0.001$ \\
\hline Present study & 0.00 & -0.07 to 0.07 & 1.00 & 0.996 \\
\hline \multicolumn{5}{|l|}{ Total $(n=1860)$} \\
\hline WHO 2007 & -0.19 & -0.25 to -0.13 & 1.29 & $<0.001$ \\
\hline USCDC 2000 & -0.24 & -0.30 to -0.18 & 1.32 & $<0.001$ \\
\hline Present study & 0.00 & -0.05 to 0.05 & 1.00 & 0.978 \\
\hline
\end{tabular}

Table 6 Weight-for-age $z$ scores relative to the international growth references for Pakistani primary school children aged five to twelve years

\begin{tabular}{|c|c|c|c|c|}
\hline \multirow[t]{2}{*}{ Reference } & \multicolumn{4}{|c|}{ Weight-for-age $z$ scores } \\
\hline & Mean & $95 \% \mathrm{Cl}$ & SD & $P$ value $^{\mathrm{a}}$ \\
\hline \multicolumn{5}{|l|}{ Boys $(n=977)$} \\
\hline WHO 2007 & $-0.22^{b}$ & -0.33 to -0.12 & 1.44 & $<0.001$ \\
\hline USCDC 2000 & -0.51 & -0.59 to -0.42 & 1.40 & $<0.001$ \\
\hline Present study & 0.00 & -0.06 to 0.06 & 1.00 & 0.988 \\
\hline \multicolumn{5}{|l|}{ Girls $(n=883)$} \\
\hline WHO 2007 & $-0.21^{c}$ & -0.31 to -0.11 & 1.34 & $<0.001$ \\
\hline USCDC 2000 & -0.45 & -0.53 to -0.36 & 1.32 & $<0.001$ \\
\hline Present study & 0.00 & -0.07 to 0.07 & 1.00 & 0.979 \\
\hline \multicolumn{5}{|l|}{ Total $(n=1860)$} \\
\hline WHO 2007 & -0.22 & -0.29 to -0.15 & 1.36 & $<0.001$ \\
\hline USCDC 2000 & -0.48 & -0.54 to -0.41 & 1.39 & $<0.001$ \\
\hline Present study & 0.00 & -0.05 to 0.05 & 1.00 & 0.983 \\
\hline
\end{tabular}

cut-offs for assessing child growth in the developing countries [39-44]. Significantly higher thinness prevalence and lower overweight and obesity prevalence were seen with use of the IOTF cut-offs as compared to the WHO and USCDC references, consistent with previous studies $[45,46]$.

Prevalence of overweight, obesity, stunting and thinness showed a significantly increasing trend with age

Table 7 BMI-for-age $z$ scores relative to the international growth references for Pakistani primary school children aged five to twelve years

\begin{tabular}{|c|c|c|c|c|}
\hline \multirow[t]{2}{*}{ Reference } & \multicolumn{4}{|c|}{ BMI-for-age z scores } \\
\hline & Mean & $95 \% \mathrm{Cl}$ & SD & P value ${ }^{a}$ \\
\hline \multicolumn{5}{|l|}{ Boys $(n=977)$} \\
\hline WHO 2007 & -0.30 & -0.41 to -0.20 & 1.60 & $<0.001$ \\
\hline USCDC 2000 & -0.51 & -0.61 to -0.42 & 2.00 & $<0.001$ \\
\hline Present study & 0.00 & -0.05 to 0.07 & 1.00 & 0.803 \\
\hline \multicolumn{5}{|l|}{ Girls ( $n=883$ ) } \\
\hline WHO 2007 & -0.34 & -0.43 to -0.25 & 1.40 & $<0.001$ \\
\hline USCDC 2000 & -0.54 & -0.63 to -0.44 & 1.44 & $<0.001$ \\
\hline Present study & 0.00 & -0.07 to 0.07 & 1.00 & 0.999 \\
\hline \multicolumn{5}{|l|}{ Total $(n=1860)$} \\
\hline WHO 2007 & -0.32 & -0.39 to -0.25 & 1.51 & $<0.001$ \\
\hline USCDC 2000 & -0.53 & -0.59 to -0.46 & 1.48 & $<0.001$ \\
\hline Present study & 0.00 & -0.04 to 0.04 & 0.99 & 0.859 \\
\hline
\end{tabular}


Table 8 Prevalence of over-nutrition relative to the international growth references among Pakistani primary school children aged five to twelve years $(n=1860)$

\begin{tabular}{|c|c|c|c|c|}
\hline \multirow[t]{2}{*}{ Reference } & \multicolumn{2}{|c|}{$\begin{array}{l}\text { Overweight } \\
>+1 \text { SD BMI-for-age } z \text { score }\end{array}$} & \multicolumn{2}{|c|}{$\begin{array}{l}\text { Obesity } \\
>+2 \text { SD BMI-for-age } z \text { score }\end{array}$} \\
\hline & n (\%) & $P$ value $^{a}$ & n (\%) & $P$ value $^{a}$ \\
\hline \multicolumn{5}{|l|}{ Boys $(n=977)$} \\
\hline WHO 2007 & $170(17.4)$ & $<0.001$ & $86(8.8)$ & $<0.001$ \\
\hline USCDC 2000 & $141(14.4)$ & & $45(4.6)$ & \\
\hline \multirow[t]{2}{*}{ IOTF $^{\mathrm{b}}$} & $74(7.6)$ & $<0.001^{c}$ & $42(4.3)$ & $<0.001^{c}$ \\
\hline & & $<0.001^{d}$ & & $0.453^{d}$ \\
\hline \multicolumn{5}{|l|}{ Girls $(n=883)$} \\
\hline WHO 2007 & $146(16.5)$ & 0.006 & $54(6.1)$ & $<0.001$ \\
\hline USCDC 2000 & $135(15.3)$ & & $30(3.4)$ & \\
\hline \multirow[t]{2}{*}{ IOTF $^{\mathrm{b}}$} & $80(9.1)$ & $<0.001^{c}$ & $45(5.1)$ & $0.422^{c}$ \\
\hline & & $<0.001^{\mathrm{d}}$ & & $<0.001^{\mathrm{d}}$ \\
\hline \multicolumn{5}{|l|}{ Total $(n=1860)$} \\
\hline WHO 2007 & $316(17.0)$ & $<0.001$ & $140(7.5)$ & $<0.001$ \\
\hline USCDC 2000 & $276(14.8)$ & & $75(4.0)$ & \\
\hline \multirow[t]{2}{*}{ IOTF $^{\mathrm{b}}$} & $154(8.3)$ & $<0.001^{c}$ & $87(4.7)$ & $<0.001^{c}$ \\
\hline & & $<0.001^{d}$ & & $0.017^{d}$ \\
\hline
\end{tabular}

${ }^{a} \mathrm{P}$ values are for difference between the estimates by the WHO 2007 and USCDC 2000 references obtained by the McNemar test

${ }^{b}$ IOTF estimates are based on cut-offs corresponding to the respective BMI cut-off value at age 18 years and above

c compared to the WHO 2007 reference, ${ }^{d}$ compared to the USCDC 2000 reference

Table 9 Prevalence of under-nutrition relative to the international growth references among Pakistani primary school children aged five to twelve years

\begin{tabular}{|c|c|c|c|c|c|c|}
\hline \multirow[t]{2}{*}{ Reference } & \multicolumn{2}{|c|}{$\begin{array}{l}\text { Stunting } \\
<-2 \text { SD height-for-age } z \text { score }\end{array}$} & \multicolumn{2}{|c|}{$\begin{array}{l}\text { Underweight } \\
<-2 \text { SD weight-for-age z score }\end{array}$} & \multicolumn{2}{|c|}{$\begin{array}{l}\text { Thinness/Wasting } \\
<-2 \text { SD BMI-for-age z score }\end{array}$} \\
\hline & $\overline{n(\%)}$ & P value ${ }^{a}$ & n (\%) & P value ${ }^{a}$ & $\mathrm{n}(\%)$ & P value $^{a}$ \\
\hline \multicolumn{7}{|l|}{ Boys $(n=977)$} \\
\hline WHO 2007 & $84(8.6)$ & 0.146 & $69(7.1)^{b}$ & $<0.001$ & $99(10.1)$ & $<0.001$ \\
\hline USCDC 2000 & $90(9.2)$ & & 126 (12.9) & & 125 (12.8) & \\
\hline \multirow[t]{3}{*}{$\mathrm{IOTF}^{\mathrm{C}}$} & - & & - & & $36(3.7)^{d}$ & $<0.001^{9}$ \\
\hline & & & & & $45(4.6)^{e}$ & $<0.001^{\mathrm{h}}$ \\
\hline & & & & & $180(18.4)^{f}$ & \\
\hline \multicolumn{7}{|l|}{ Girls $(n=883)$} \\
\hline WHO 2007 & $68(7.7)$ & 0.774 & $56(6.3)^{i}$ & $<0.001$ & $89(10.1)$ & $<0.001$ \\
\hline USCDC 2000 & $70(7.9)$ & & $104(11.8)$ & & 119 (13.5) & \\
\hline \multirow[t]{3}{*}{$\mathrm{IOTF}^{\mathrm{C}}$} & - & & - & & $31(3.5)^{d}$ & $<0.001^{9}$ \\
\hline & & & & & $70(7.9)^{\mathrm{e}}$ & $0.003^{h}$ \\
\hline & & & & & $166(18.8)^{f}$ & \\
\hline \multicolumn{7}{|l|}{ Total $(n=1860)$} \\
\hline WHO 2007 & $152(8.2)$ & 0.169 & $125(6.7)^{j}$ & $<0.001$ & $188(10.1)$ & $<0.001$ \\
\hline USCDC 2000 & $160(8.6)$ & & $230(12.4)$ & & $244(13.1)$ & \\
\hline \multirow[t]{3}{*}{$\mathrm{IOTF}^{\mathrm{C}}$} & - & & - & & $67(3.6)^{d}$ & $<0.001^{\mathrm{g}}$ \\
\hline & & & & & $115(6.2)^{\mathrm{e}}$ & $<0.001^{\mathrm{h}}$ \\
\hline & & & & & $346(18.6)^{f}$ & \\
\hline
\end{tabular}

\footnotetext{
a P values are for difference between the estimates by the WHO 2007 and USCDC 2000 references obtained by the McNemar test

${ }^{\mathrm{b}} \mathrm{n}=747$ (boys aged five to ten years) for underweight prevalence with the WHO 2007 reference

c IOTF estimates are based on cut-offs corresponding to the respective BMI cut-off value at age 18 years and above

${ }^{d}$ Thinness grade three, ${ }^{e}$ Thinness grade two, and ${ }^{f}$ Thinness grade one

${ }^{g}$ grade one thinness compared to the WHO 2007 reference, ${ }^{\mathrm{h}}$ grade one thinness compared to the USCDC 2000 reference

${ }^{i} \mathrm{n}=699$ (girls aged five to ten years), and $\mathrm{n}=1446$ (children aged five to ten years) for underweight prevalence with the WHO 2007 reference
} 
and grade $[47,48]$. Significant correlates of overweight and obesity included urban area with high socioeconomic status (SES), higher parental education and residence in high-income neighborhoods while stunting and thinness were significantly associated with rural area and urban area with low SES, lower parental education and residence in low-income neighborhoods [47-49].

\section{Conclusions}

Pakistani school-aged children significantly differed from the WHO and USCDC references. However, z score means relative to the WHO reference were closer to zero and the present study as compared to the USCDC reference. Overweight and obesity were significantly higher while underweight and thinness/wasting were significantly lower relative to the WHO reference as compared to the USCDC reference and the IOTF cut-offs. New growth charts for Pakistani children based on a nationally representative sample should be developed. Nevertheless, shifting to use of the 2007 WHO child growth reference might have important implications for child health programs and primary care pediatric clinics.

\section{Acknowledgements}

We dedicate the work to loving memories of Ubeera Shahid (1987-2010, Allama labal Medical College Class of 2011) who left us in an unfortunate motorway car accident. We are grateful to Professor Arif M Siddiqui, MBBS, MD, MRCP, FRCP, Haris S Sheikh, MBBS-III, and other research associates at the Ubeera Memorial Research Society of Allama Iqbal Medical College, Lahore, Pakistan. We would like to thank Dina Kakar, MD, Andrea Lyman, MD, MSc, MS and Douglas Proops MD, MPH. We are indebted to children, parents and staff at the sampled schools. We acknowledge partial financial support from Allama labal Medical College and technical support from the Punjab Departments of Health and Education, Lahore, Pakistan.

\section{Author details}

'Ubeera Memorial Research Society, Allama lqbal Medical College, Lahore 54000, Pakistan. ${ }^{2}$ District Health Office Nankana Sahib, Punjab Department of Health, Nankana, Sahib 39100, Pakistan.

\section{Authors' contributions}

MUM, principal investigator, conceived and implemented the study, analyzed and interpreted the data, prepared the manuscript and supervised the entire project. SG and KM contributed to the study analysis, interpretation and manuscript preparation. HMA and UK participated in the study implementation and manuscript preparation. US contributed to the study conception, implementation and analysis. MAS and JA oversaw the study conception, implementation and manuscript preparation. All authors read and approved the final manuscript.

\section{Competing interests}

The authors declare that they have no competing interests.

Received: 25 September 2011 Accepted: 19 March 2012 Published: 19 March 2012

\section{References}

1. World Health Organization: Physical status: the use and interpretation of anthropometry. Report of a WHO Expert Committee. Technical Report Series No. 854. Geneva 1995.

2. Gelander L: Children's growth: a health indicator and a diagnostic tool. Acta Paediatr 2006, 95:517-518.
3. Cole TJ: Growth references and standards. Human Growth and Development San Diego: Academic; 2006.

4. Victora CG, Adair L, Fall C, et al: Maternal and child undernutrition: consequences for adult health and human capital. Lancet 2008, 371:340-57.

5. de Onis M, Wijnhoven TMA, Onyango AW: Worldwide practices in child growth monitoring. J Pediatr 2004, 144:461-465.

6. Robert SB, Dallal GE: The new childhood growth charts. Nutr Rev 2001, 59:31-36.

7. Zuguo M, Ray Y, Grummer-Strawn LM, Trowbridge FL: Development of a research child growth reference and its comparison with the current international growth reference. Arch Pediatr Adolesc Med 1998, 152:471-479.

8. Garza C, de Onis M: A new international growth reference for young children. Am J Clin Nutr 1999, 70:s169-172.

9. de Onis M, Onyango AW, Borghi E, Siyam A, Nishida C, Siekmann J: Development of a WHO growth reference for school-aged children and adolescents. Bull World Health Organ 2007, 85:660-667.

10. Kuczmarski RJ, Ogden CL, Guo SS, et al: 2000 CDC growth charts for the United States: methods and development. Vital Health Stat 2002, 11:1-190.

11. de Onis M, Onyango AW: The Centers for Disease Control and Prevention 2000 growth charts and the growth of breastfed infants. Acta Paediatr 2003, 92:413-419.

12. Pakistan Census Organization, Government of Pakistan: Census Report of Pakistan 1998. Islamabad 1998.

13. ZT Mechanical Physician Scale, East High Scales, China Scale Manufacturer, Nanjing, China. [http://www.easthighscale.com/ZTMechanical-Physician-Scale.html].

14. Cole TJ, Green PJ: Smoothing reference centile curves: the LMS method and penalized likelihood. Stat Med 1992, 11:1305-19.

15. Pan H, Cole T: LMS growth. Medical Research Council, United Kingdom, 200207 South Shields: Harlow Printing Limited; 2008 [http://www. healthforallchildren.co.uk/pro.epl?DO=USERPAGE\&PAGE=Imsdownload].

16. WHO AnthroPlus for personal computers Manual: Software for assessing growth of the world's children and adolescents. Geneva, Switzerland: WHO; 2009 [http://www.who.int/growthref/tools/en/].

17. World Health Organization: WHO Child Growth Standards.[http://www. who.int/growthref/en/].

18. Centers for Disease Control and Prevention: Growth charts.[http://www.cdc. gov/nccdphp/dnpa/growthcharts/resources/].

19. US Centers of Disease Control and Prevention, the Pediatric Nutrition Surveillance System: Growth Indicators.[http://www.cdc.gov/pednss/ what_is/pednss_health_indicators.htm\#growth].

20. Cole TJ, Bellizzi MC, Flegal KM, Dietz WH: Establishing a standard definition for child overweight and obesity worldwide: international survey. BMJ 2000, 320:1240-1243.

21. Black R, Morris S, Bryce J: Where and why are 10 million children dying every year? Lancet 2003, 361:2226-2234

22. Ezzati M, Hoorn SV, Rodgers A, Lopez AD, Mathers CD, Murray CJ: Estimates of global and regional potential health gains from reducing multiple major risk factors. Lancet 2003, 362(9380):271-280.

23. United Nations, Standing Committee on Nutrition: The fifth report on the world nutrition situation: Nutrition for improved development outcomes. New York 2004

24. de Onis M, Frongillo EA, Blossner M: Is malnutrition declining? An analysis of changes in levels of child malnutrition since 1980. Bull World Health Organ 2000, 78:1222-1233.

25. Jafar TH, Qadri Z, Islam M, Hatcher J, Bhutta ZA, Chaturvedi N: Rise in childhood obesity with persistently high rates of undernutrition among urban school-aged Indo-Asian children. Arch Dis Child 2008, 93(5):373-378.

26. World Health Organization: Global Strategy on Diet, Physical Activity and Health. Geneva 2004

27. Dietz WH, Robinson TN: Overweight children and adolescents. N Engl J Med 2005, 352:2100-2109.

28. Han JC, Lawlor DA, Kimm SYS: Childhood obesity. Lancet 2010, 375:1737-1748.

29. Prentice AM: The emerging epidemic of obesity in developing countries. Int J Epidemiol 2006, 35:93-99.

30. Ma J, Wang Z, Song Y, Hu P, Zhang B: BMI percentile curves for Chinese children aged 7-18 years, in comparison with the WHO and the US 
Centers for Disease Control and Prevention references. Public Health Nutr 2010, 13(12):1990-1996.

31. Rosario AS, Kurth BM, Stolzenberg H, Ellert U, Neuhauser H: Body mass index percentiles for children and adolescents in Germany based on a nationally representative sample (KiGGS 2003-2006). Eur J Clin Nutr 2010, 64(4):341-349.

32. Guedes DP, De Matos JA, Lopes VP, Ferreirinha JE, Silva AJ: Physical growth of schoolchildren from the Jequitinhonha Valley, Minas Gerais, Brazil: Comparison with the CDC-2000 reference using the LMS method. Ann Hum Biol 2010, 37(4):574-584.

33. Al Herbish AS, El Mouzan MI, Al Salloum AA, et al: Body mass index in Saudi Arabian children and adolescents: a national reference and comparison with international standards. Ann Saudi Med 2009, 29:342-347.

34. Novotny R, Daida YG, Grove JS, Le Marchand L, Vijayadeva V: Asian adolescents have a higher trunk:peripheral fat ratio than Whites. J Nutr 2006, 136:642-647.

35. He Q, Horlick M, Thornton J, et al: Sex and race differences in fat distribution among Asian, African-American, and Caucasian prepubertal children. J Clin Endocrinol Metab 2002, 87:2164-2170.

36. Khadilkar W, Khadilkar AV, Borade AB, Chiplonkar SA: Body Mass Index Cut-offs for Screening for Childhood Overweight and Obesity in Indian Children. Indian Pediatr 2011, [pii: S09747559INPE1000147-1. Epub ahead of print].

37. Razak F, Anand SS, Shannon $\mathrm{H}$, et al: Defining obesity cut points in a multiethnic population. Circulation 2007, 115:2111-2118.

38. Bhargava SK, Sachdev HS, Fall CH, et al: Relation of serial changes in childhood body-mass index to impaired glucose tolerance in young adulthood. N Engl J Med 2004, 350:865-875.

39. Fetuga MB, Ogunlesi TA, Adekanmbi AF, Alabi AD: Growth Pattern of Schoolchildren in Sagamu, Nigeria Using the CDC Standards and 2007 WHO Standards. Indian Pediatr 2011, 48(7):523-8.

40. de Onis M, Garza C, Onyango AW, Borghi E: Comparison of the WHO child growth standards and the CDC 2000 growth charts. J Nutr 2007, 137(1):144-148.

41. Bosman L, Herselman MG, Kruger HS, Labadarios D: Secondary Analysis of Anthropometric Data from a South African National Food Consumption Survey, Using Different Growth Reference Standards. Matern Child Health J 2010.

42. Schwarz NG, Grobusch MP, Decker ML, et al: WHO 2006 child growth standards: implications for the prevalence of stunting and underweightfor-age in a birth cohort of Gabonese children in comparison to the Centers for Disease Control and Prevention 2000 growth charts and the National Center for Health Statistics 1978 growth references. Public Health Nutr 2008, 11(7):714-719.

43. Stigler MH, Arora M, Dhavan $\mathrm{P}$, et al: Measuring obesity among schoolaged youth in India: a comparison of three growth references. Indian Pediatr 2011, 48(2):105-110

44. Nuruddin R, Lim MK, Hadden WC, Azam I: Comparison of estimates of under-nutrition for pre-school rural Pakistani children based on the WHO standard and the Nationa Center for Health Statistics (NCHS) reference. Public Health Nutr 2009, 12(5):716-722.

45. Kain J, Uauy R, Vio F, Albala C: Trends in overweight and obesity prevalence in Chilean children: comparison of three definitions. Eur J Clin Nutr 2002, 56(3):200-204.

46. Krebs NF, Himes JH, Jacobson D, Nicklas TA, Guilday P, Styne D: Assessment of Child and Adolescent Overweight and Obesity. Pediatrics 2007, 120:S193-S228.

47. Mushtaq MU, Gull S, Abdullah HM, Shahid U, Shad MA, Akram J: Prevalence and socioeconomic correlates of overweight and obesity among Pakistani primary school children. BMC Public Health 2011, 11(1):724.

48. Mushtaq MU, Gull S, Khurshid U, Shahid U, Shad MA, Siddiqui AM: Prevalence and socio-demographic correlates of stunting and thinness among Pakistani primary school children. BMC Public Health 2011, 11(1):790.

49. Mushtaq MU, Gull S, Mushtaq K, Shahid U, Shad MA, Akram J: Family-based factors associated with overweight and obesity among Pakistani primary school children. BMC Pediatr 2011, 11(1):114.

\section{Pre-publication history}

The pre-publication history for this paper can be accessed here: http://www.biomedcentral.com/1471-2431/12/31/prepub

doi:10.1186/1471-2431-12-31

Cite this article as: Mushtaq et al:: Height, weight and BMI percentiles and nutritional status relative to the international growth references among Pakistani school-aged children. BMC Pediatrics 2012 12:31.

\section{Submit your next manuscript to BioMed Central and take full advantage of:}

- Convenient online submission

- Thorough peer review

- No space constraints or color figure charges

- Immediate publication on acceptance

- Inclusion in PubMed, CAS, Scopus and Google Scholar

- Research which is freely available for redistribution

Submit your manuscript at www.biomedcentral.com/submit
Biomed Central 